\title{
An Analysis Of Social Skills In The Problem Based Learning Model Reviewed From The Cognitive Style
}

\author{
Ade Bagus Primadoni ${ }^{1}$, Erni Suharini ${ }^{2}$, Mulyono $^{3}$ \\ \{adebagus303@gmail.com,erni.suharini@mail.unnes.ac.id,mulyono@mail.unnes.ac.id\} \\ Universitas Negeri Semarang ${ }^{1,2,3}$
}

\begin{abstract}
The social skills of elementary school students during the learning process still show selfishness, individualism, and only gather with their chosen group. Therefore, the collaboration between students is less established and the social skills of students are less developed. The research objective was to describe the social skills of fourth grade students with the problem based learning (PBL) model of mathematics learning in terms of cognitive style. The research method used in this study was descriptive qualitative method with case study design. The data collection technique used were tests, observations, and interviews. The population in this study was grade IV SDN Karangtengah 01 and the research subjects consisted of teachers and students who were divided into independent field cognitive subject (FI) and field dependent (FD) subjects. The results showed that the FD subject social skills were better than the FI subjects, however, the FI subject learning outcomes were better than the FD subjects.
\end{abstract}

Keywords : Social Skill, PBL, Cognitive Style

\section{Introduction}

Students in their development must be inseparable from the name of social life, from where social skills skills are needed so that students are able to place themselves and take appropriate roles in their environment, but it turns out that the social skills of elementary school students while teaching and learning still show selfishness, individualism, and only want to gather with the chosen group, while here the teacher still tends to use conventional learning and sticks to the book material so that students in learning become bored, lack of attention, lack of concentration and students lack cooperation in groups. Various manifestations of social skills possessed by children, including children able to establish relationships and interact with their environment. Therefore, it would be good in learning to try to use learning that is innovative and can improve social skills.

The learning model used in this study was a problem based learning (PBL) model. Learning with the problem based learning (PBL) model is a teaching approach that challenges students to find solutions to individual (group) real-world (open) problems (Mohamad in Setiawan: 2017) ${ }^{[1]}$. This is in line with the research conducted by Atmojo (2012) who stated that the Problem Based Learning model with SETS vision can improve the social skills of fourth grade students at SD Sonosewu Kasihan Bantul ${ }^{[2]}$, as well as research conducted by Khairat (2013) stated that Problem Based Learning learning models can improve social skills students ${ }^{[3]}$. Problem-based learning models can improve mathematics learning, curiosity, 
independence, collaboration, students' social skills both with friends and teachers (Liyandari: 2013) ${ }^{[4]}$.

In the above research, there has been no discussion of research on student cognitive styles, namely the way someone processes, stores and uses information to respond to a task or various types of environment (Ngilawajan: 2013) ${ }^{[5]}$. Basically cognitive style focuses on the characteristics of individual consistency in terms of how he thinks, remembers, processes information and solves problems (Dornyei in Suida: 2017) ${ }^{[6]}$. In this cognitive style is divided into two, namely cognitive style Field Independent (FI) and Field Dependent (FD).

This study is intended to describe the social skills of class IV students with a problem based learning (PBL) model on mathematics learning in terms of cognitive style, the benefits of doing this research so that teachers can meet the needs of students' cognitive style characteristics to facilitate understanding the learning material.

\section{Method}

This study applied a qualitative descriptive method with a case study design. Sources of data in this study were in the form of observations and interviews to find out social skills during learning with PBL models in class IV SDN Karangtengah 01, Subah District, academic year 2017/2018. The subjects of the study consisted of fourth grade teachers and four students of grade IV who were divided into two students as subjects of independent field cognitive style (FI) and two students as field dependent subjects (FD). Data collection techniques used were tests, observations, and interviews. The test technique is carried out to students to find out the cognitive style of each student, the test here uses the Group Embedded Figures Test (GEFT) instrument that has been developed by experts. Observations were made on students who were the subjects of research in order to find out every social skill in learning mathematics with the PBL model, meanwhile, interviews were conducted with teachers and students as the subjects of the study to obtain data regarding about these social skills.

The validity test of the data was done through the process of triangulating data sources carried out from the results of observations and interviews with the subject. The analysis technique uses the method of interactive data analysis in Milles and Habermen's model through the stages of data reduction, data presentation and conclusion drawing.

\section{Results and Discussion}

\subsection{Analysis of Social Skills Viewed from the Cognitive Style of Students}

Based on the results of the analysis of observations and interviews in this study the following results were obtained. (1) cognitive field independent (FI) subjects show that in good collaboration skills this can be seen from being enthusiastic with their group mates, as well as in adaptation skills, both of which are ready for one group with anyone, and can interact with his group friends well. However, in self-control skills, it is good enough to be able to share opportunities with friends when communicating the results of discussions, while in empathic skills it is good to give appreciation when other groups succeed in answering questions, skills in obeying regulations are good when following agreed rules, and in skills respect for others is also good for not disturbing when other groups are presenting. (2) the 
subject with field dependent cognitive style (FD) shows that in the skill of cooperating very well this can be seen from the very enthusiasm with his group mates, for the skill in adjusting is also good in terms of willingness to be with one group, and in interacting skills can communicate very well in the group environment. As well as in self-control skills it is also very good to share opportunities with friends when communicating the results of the discussion, in empathy skills can also be very appreciative of other groups who successfully complete the task. For the skill to obey the rules, it is very possible to follow every rule that has been agreed both in learning and groups, in the skills of respecting other people very well in not disturbing when other groups are presenting and paying attention to the group's presentation.

\subsection{Analysis of Problem Based Learning (PBL) Model on Social Skills}

Subjects with independent field cognitive style (FI1) showed an increase in social skills, based on the results of observations during the study took place with the percentage of each observation that is $48 \%, 71 \%, 76 \%$, and $85 \%$. Similar to FI1 subjects, subjects with independent cognitive style feild (FI2) also showed an increase in social skills during learning, seen from the results of observations during the study took place with the percentage of each meeting that is $46 \%, 68 \%, 73 \%$, and $81 \%$.

Furthermore, there were also an increase in the social skills in subjects with cognitive feild dependent (FD) style, reviewed from the results of observations, each study took place on FD1 subjects getting the percentage of each meeting which was $57 \%, 71 \%, 81 \%$, and $89 \%$. This also happened in FD2 subjects showing an increase in social skills. Based on the results of observations when FD2 subject research was conducted, the percentage of each meeting was $56 \%, 79 \%, 90 \%$, and $90 \%$. The graph of the increase of social skills is presented in the following Figure 1.

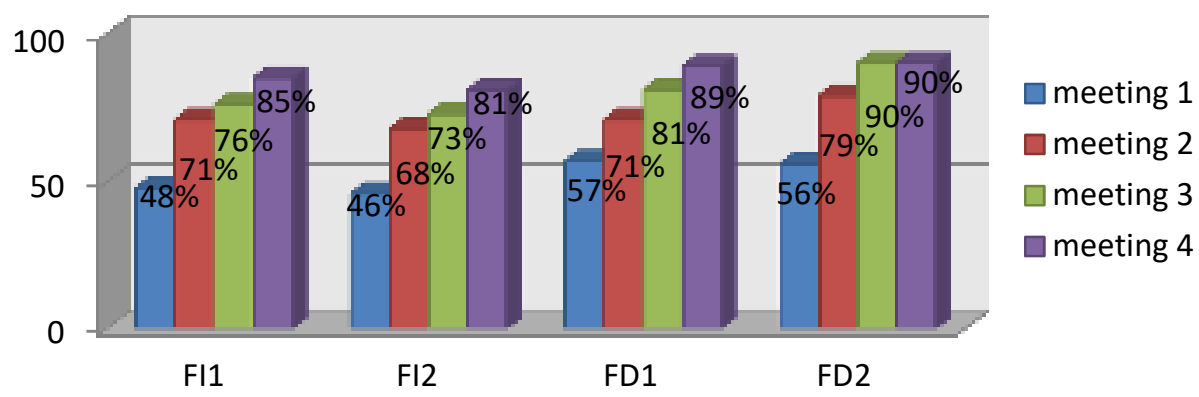

Figure 1. Graph of the Increase of Social Skills

Learning with PBL models in this study provides results that students' social skills with cognitive style (FD) are better than cognitive styles (FI), FI cognitive styles in learning are more independent by prioritizing analytical thinking skills and systematic, but besides that they experience difficulties in mastering the social sciences, meanwhile students with FD cognitive styles prioritize environmental influences in relation to social relations (Darmono, 2012) ${ }^{[7]}$. A similar thing was expressed by Rati (2013). The cognitive style of FI is a person's 
cognitive style with a high degree of independence in observing a stimulus without dependence on external factors and lack of cooperation, whereas FD's cognitive style is a cognitive style that tends to be very rely on outside sources of information and work together better with others ${ }^{[8]}$.

Moreover, the PBL model in this study can improve students' social skills, in another study also explained that the PBL model can improve the social skills of fifth grade students of elementary school (Dewi, $2016^{[9]}$; Khairat, 2013 ${ }^{[3]}$ ). Pertiwi (2014) also explained the application of PBL learning models can improve social skills in terms of independence, responsibility, cohesiveness, and mutual respect ${ }^{[10]}$. This is in accordance with the opinion of Atmojo (2014) SETS learning model Problem Based Learning as a set of learning strategies in the classroom has been able to train students to work together in discussions and respect friends and others ${ }^{[2]}$. Based on these explanations the PBL model provides opportunities for students to develop social skills through discussions to solve problems in groups, so that better interactions among friends can occur.

\section{Conclusion}

Based on the results and discussion, it can be concluded that the learning using the PBL model for students who have an independent feild cognitive style (FI) has an excess level of high independence, is not easily affected by the surrounding environment so that it is easy to master the material provided. Lack of cognitive style (FI) is not easy to socialize with the surrounding environment so that social skills are lacking. In contrast to the cognitive style of feild dependent (FD) having high social skills however,the learning outcomes was in the less category since students were easily disturbed by the surrounding environment to understand a learning material. This makes the teachers in the class have to be able to understand the character of the students better so that the teacher must be more creative in the learning in order to minimize the existing shortcomings. 


\section{References}

[1] Setiawan, A, M., Dwi, A, B., \& Budhi Utami. 2017. "Pengaruh Model Pembelajaran Problem Based Learning Dipadu Student Facilitator and Explaining Terhadap Kemampuan Berpikir Kritis Siswa Kelas X SMAN 6 Kediri Pada Pokok Bahasan Fungi”. Jurnal Florea. 4(1): 1-4.

[2] Atmojo, S. E. 2013. "Pembelajaran IPA Sekolah Dasar Model Problem Based Learning Bervisi SETS Untuk Meningkatkan Keterampilan Sosial Siswa". DIDAKTIKA, 4(1): 344-357.

[3] Khairat. 2013. "Peningkatan Keterampilan Sosial Pada Pelajaran IPS Melalui Implementasi Model Pembelajaran Problem Based Learning Pada Siswa Di Kelas IV SD Negeri 067774 Kelurahan Suka Maju Medan Johor T.P. 2012/2013”. Jurnal Tematik. 3(12): 1-17.

[4] Liyandari., Wahyudi., \& Imam, S. 2013. "Penggunaan Model Pembelajaran Berbasis Masalah dalam Peningkatan Pembelajaran Matematika Tentang Pecahan Siswa Kelas IV SD". Kalam Cendekia PGSD Kebumen, 4(1): 1-6.

[5] Ngilawajan, D. A. 2013. "Proses Berpikir Siswa SMA Dalam Memecahkan Masalah Matematika Materi Turunan Ditinjau Dari Gaya Kognitif Field Independent Dan Field Dependent". PEDAGOGIA: Jurnal Pendidikan, 2(1): 71-83.

[6] Suida, M., \& Lambertus. 2017. "Profile of High School Athematical Reasoning To Solve The Problem Mathematical Viewed From Cognitive Style". International Journal of Education and Research, 5(6): 163-174.

[7] Darmono, A. 2012. "Identifikasi Gaya Kognitif (Cognitive Style) Peserta Didik Dalam Belajar". Jurnal Studi Islam dan Sosial, 3(1): 63-69.

[8] Rati, N. W. 2013. "Pengaruh Model Pembelajaran Kuantum Bermuatan Peta Pikiran dan Gaya Kognitif terhadap Hasil Belajar". Jurnal Pendidikan dan Pengajaran, 46(1): 55-65.

[9] Dewi, S., Sumarmi, \& Amirudin, A. 2016. "Penerapan Model Pembelajaran Problem Based Learning untuk Meningkatkan Keaktifan dan Keterampilan Sosial Siswa Kelas V SDN Tangkil 01 Wlingi”. Jurnal Pendidikan: Teori, Penelitian, dan Pengembangan, 1(3): 281-288.

[10] Pertiwi, K. R., Yuliati, Y., \& Rahayu, T. 2014. "Profil Proses Sains dan Keterampilan Sosial Mahasiswa pada Pembelajaran Sistem Digesti Melalui Penerapan Seven Jump Problem-Based Learning”. Jurnal Pendidikan Matematika dan Sains, 2(1): 65-74. 